\title{
RESEARCHING GLOBALISATION: LESSONS FROM JUDICIAL CITATIONS
}

John Bell

\begin{abstract}
Professor John Bell delivered an abbreviated version of these remarks as the Closing Address to the Third Annual CJICL Conference on Sunday, 11 May 2014 at the Divinity School of St John's College in the University of Cambridge. In them, Professor Bell addresses the assumption of the unifying force of universality and cosmopolitanism and how the citation of foreign laws by national judges affects the validity of such an assumption from the point of view of legal research.
\end{abstract}

In the conference programme, the organisers made two assertions as the basis of its challenge to the traditional state-centric view of international and comparative law. The idea of universality suggests that international law applies equally and indiscriminately across domestic legal systems, and within sub-systems of international law itself. Cosmopolitanism conceives of the world as a single entity, with resonances between people irrespective of their location, nationality and culture, and asks how legal actors can access legal regimes beyond their state's domestic framework.

Within a university, such a cross-national approach is typical. Since the Middle Ages, the great universities have been centres to which students of different nationalities have come to study under cosmopolitan teachers. This tendency has increased in recent years, particularly with the growth of postgraduate studies. The question is how far this approach works as a valid assumption for legal research. This paper argues that the national (or sub-national) legal system remains an important feature of legal experience and needs to be factored into any project on globalisation. The challenge for research is to determine a method that reflects both the insight of the conference and the importance of the national legal system. I will take one area of recent comparative law literature to illustrate the limits on how research can cast light on the extent to which the global legal world envisaged by the conference organisers really exists. The topic I have used is the citation of foreign laws by national judges, since this is often used as an indicator of the extent to which national judges conceive of themselves as participants in a global debate about what are appropriate solutions to contemporary problems.

\footnotetext{
Professor of Law, University of Cambridge.
} 


\section{The place of the national legal system}

The plausibility of a displacement of the nation state in the contemporary legal world is enhanced by its fragility as an organiser of social affairs. Legal history demonstrates that many 'nation state' boundaries are artificial. Towns on the continent of Europe (as well as in Africa and Asia) have tolerated the imposition of different national governments, often in rapid succession. So there is scope for national law to be displaced by other norms in governing particular situations. Furthermore, in the world after 1945, there has been an increased use of international or regional treaties and organisations to deal with problems. The increased ease of transport and communications have made cooperation across national boundaries an increasingly important part of the handling of issues by national legal orders.

All the same, legal systems that have been produced within nation states have many enduring effects and can create path dependence in the approach to common problems. To begin with, lawyers are formed typically within specific national legal systems and belong to national legal professions. Such qualifications are generally a requirement for acting on an international stage. The prior formation that this provides can lead to such lawyers, whether as advocates, judges or arbitrators, adopting distinctive national approaches to the solution of problems. If there are established ways of doing things, then national lawyers trained in that tradition will be hard to shift. This can be the result, not of conservatism amongst lawyers, but of path dependence.

'Path dependence' suggests that 'established legal approaches to the solution of issues will determine the way in which new situations or new problems are handled in the present and in the future. ${ }^{1}$ As Siems points out, 'path dependence' can take various forms. ${ }^{2}$ What he calls the 'weak version' might equally be described as the 'good enough' approach. In this, the solution reached by national law comes to a good enough result or reaches it by a good enough method that there seems to be no great benefit in changing this. His 'semi-strong' path dependency involves recognition that the result or the method is not good, but the cost of doing something different is prohibitive. His 'strong' path dependence is 'why change?' when there is no acceptance that the solution or method are bad. Most of what we encounter is of the first two kinds. Even if we have common objectives, there may not be a single preferable outcome or route to an outcome.

\footnotetext{
1 J Bell, 'Path Dependence and Legal Development' (2013) 87 Tulane LR 787.

2 M Siems, Comparative Law (2014) 239.
} 
If a plurality of approaches can reach good enough results, then there is no need to adopt a common stance. An obvious area is criminal procedure. Some systems have a judge-led inquiry (at least for serious cases) and then a trial in which the file of evidence accumulated is available to all parties, including the judges. Other systems have a police-led investigation and a need to re-present evidence to the trial judge (and jury). Others have a significant role for the prosecutor. Given that each of the systems produces fair trials most of the time, there is little pressure for change. Lawyers used to working in one particular system do not then change it. $^{3}$

Semi-strong path dependence can be shown by the way in which the procedure for the sale of land in Scotland and England has not been harmonised. It is generally recognised that the English system of accepting an offer on your house 'subject to contract' can lead to undesirable practices whereby the buyer threatens to pull out unless the price is reduced (gazundering) or the seller requires a higher price (gazumping) at a late stage in negotiations. In Scotland, this does not occur, since offers are binding on acceptance. Yet the two countries have continued to operate these distinct systems for centuries, despite the number of people who buy property in Scotland financed by a sale of property in England, or vice versa. ${ }^{4}$ So much of the English system of lawyers, estate agents, banks etc. is designed around the current English practice that it would be hard to change.

Situations of sheer incomprehension between legal systems are rarer, and that may be the point of the conference theme. Shared values in relation to shared problems will reduce the situations in which there is incomprehension. One example might be the use of lay judges. The fact that about $95 \%$ of all criminal cases in England are resolved by three lay magistrates is frequently greeted with astonishment by lawyers from other countries. How can this be a fair trial? But if you make them sit through a morning at a local magistrates' court, they are satisfied that the trial is fair, but it is not something they would be willing to apply at home. In some other countries, the non-professional judge (also carrying the label 'justice of the peace') has a legal education. ${ }^{5}$ Attitudes to the death penalty might be seen as extreme versions of strong path dependence where some systems see nothing wrong with the practice and others see it as both morally and legally

3 See J Bell, 'The French Pre-Trial System', in C Walker \& K Starmer (eds), Miscarriages of Justice (1999) ch 17.

${ }^{4}$ Cf R Smith, Property Law ( $8^{\text {th }}$ edn, 2014) 101-7; T Guthrie, Scottish Property Law (2 ${ }^{\text {nd }}$ edn, 2005) 271-3.

${ }^{5}$ See J Bell, Judiciaries with Europe (2006) 330; cf ibid, 89-94 (France), 154-8 (Germany) and 207-11 (Spain). 
repugnant. These two features of legal systems, professional formation and path dependence, give rise to the hypothesis that problems will not always be solved in the same legal way in every jurisdiction, even if all other features (social culture, political ideology, etc.) remain the same across the different countries.

\section{What constitutes globalisation of law?}

The organisers of the Conference point to the importance of international law in the regulation of problems. Areas such as crimes against humanity, trade relations between states and the protection of investors are subject to various forms of international law, which have spawned new branches of that discipline and have reduced the scope for autonomous national provisions. In many areas of life, the nation state has to pay heed to the norms of international law. But the organisers go further in suggesting that there has also been a much more extensive globalisation of law that has reduced the significance of national law in other important respects.

Siems presents a number of dimensions of the supranational direction of contemporary law. ${ }^{6}$ The first is that national laws are subject to external influences leading to the convergence of legal provisions, if not outright harmonisation. The second is that problems are resolved by regional groupings of states, so there are common regional laws. Thirdly, a problem may be resolved by non-state law that transcends national boundaries, transnational law. In these different ways, the specific national solution gives way to other solutions. The specific rule applied may be a national norm, but it has to be appreciated as part of a more international whole. The analysis is not that the state fades away, but that the state may be less important than other actors in relation to specific problems. Public and private ordering have to be considered as dimensions of contemporary law and that may happen at a number of levels, some of which extend beyond the nation state. The paradigm of state ordering is autonomy in deciding the content and the implementation of the norms that apply to situations within the territory of the nation state.

Furthermore, the conference theme raises the major question whether it is best to focus attention on nation states or legal systems or to focus on particular problems, some of which may be resolved at nation state level (or even infra-state level) and some of which may be resolved by a combination of nation state, regional and international standards, and even by both public sector and private

${ }^{6}$ M Siems, Comparative Law (2014) ch 9. 
sector norms. Whereas speed restrictions on motor vehicles in residential areas or the duty to provide playground facilities for children under ten may be fully regulated by local or national law, the treatment of asylum seekers may be regulated by a combination of international treaties on rights to asylum, regional rules on the handling of asylum claims, national immigration and social benefits law and local rules on social benefits and legal entitlements under private charitable trusts. Whereas it does not make sense to conceive of all the activities of a national legal order in the light of international law, nor does it make sense always to examine problems with an exclusive focus on the domestic legal system. A number of the studies which will be examined in more depth later in this article conclude that the use of comparative law materials varies from one topic to another. For example, Groppi and Ponthoreau draw a distinction between human rights cases ${ }^{7}$ and institutional decisions, those about the operation of the organs of state. They and their colleagues conclude that judges are more likely to cite foreign precedents in cases about human rights than about the institutions of government. Human rights norms have more obvious claims to be universal, not only because there are international law reference points. The human condition and values such as human dignity are not specific to particular countries. By contrast, the roles of presidents and legislators can be very specific. There are lots of other examples. Thus, a more sectorial approach to the place of international and comparative law is the way forward, rather than focusing on grand scale claims about globalisation.

Siems reminds us effectively that, on the one hand it is important to recognise that the nation state is not necessarily the central actor in handling problems in the contemporary world-the problem may be governed by supranational norms of various kinds, or it may even not be resolved by public sector norms at all. On the other hand, the national legal system may have a distinctive path in the resolution of such problems. On the topic of globalisation, one indicator much discussed in the literature is the frequency of the citation of foreign legal sources in judicial decisions. Many studies have examined the extent to which it is permissible for the justifications provided by a national judge to include decisions drawn from another legal system and how far this is practised. Such studies are often ways of assessing how far national legal systems have become more globalised.

\footnotetext{
7 T Groppi \& M-C Ponthoreau, 'Conclusion. The Use of Foreign Precedents by Constitutional Judges: A Limited Practice, An Uncertain Future', in T Groppi \& M-C Ponthoreau (eds), The Use of Foreign Precedents by Constitutional Judges (2013) 411, 416-18.
} 
A distinction must be drawn between the extent to which judges consider themselves part of an international enterprise because they are applying (mandatory) texts shared in common with other countries, and where they make use of (non-mandatory) texts to help them deal with situations in which national law is lacking, defective or in need of reform. In the former situation, there is plenty of evidence that judges engage with each other in determining the meaning of mandatory texts. Thus, in relation to the challenge for national judges of interpreting the European Convention on Human Rights and European Union law, Mak states:

The majority of the judges who were interviewed for this book feel that they have been challenged by these changes to develop new strategies concerning the search for and weighing of arguments in their decision-making, and to develop judicial leadership through their engagement as 'partners in a common judicial enterprise. ${ }^{8}$

But if there is good reason for courts to consider themselves partners with others in the interpretation of the same treaty, does this extend to the solution of legal problems more generally? Former President of the French Cour de cassation, Canivet, has argued that it should:

Citizens and judges of States which share more or less similar cultures and enjoy an identical level of economic development are less and less prone to accept that situations which raise the same issues of fact will yield different results because of the differences in the rules of law to be applied. This is true in the field of bioethics, in that of economic law and liability. In all these cases, there is a trend, one might even say a strong demand, that compatible solutions are reached, regardless of the differences in the underlying applicable rules of law. ${ }^{9}$

This kind of assertion has given rise to some interesting research in recent years that suggests that the picture may be more complex than this sort of quotation suggests.

${ }^{8}$ E Mak, Judicial Decision-Making in a Globalised World (2013) 83; see also ibid, 141-50.

9 Guy Canivet, cited in M Andenas \& D Fairgrieve, 'Introduction: Finding a Common Language for Open Legal Systems', in G Canivet, M Andenas \& D Fairgrieve (eds), Comparative Law Before the Courts (2004) xxvii, xxxi. 


\section{Researching globalisation through judicial citations}

Much of the recent evidence adduced to demonstrate globalisation comes from the analysis of judicial decisions. There has been writing on this subject for a number of years, not just that triggered specifically by Justice Scalia's comments. ${ }^{10}$ Writing in 1994, Ulrich Drobnig noted that there was little evidence of widespread use of comparative law by courts in cases where it was neither necessary (such as when applying general principles of international law or general principles of law) nor where the national rule at issue involved an international element-for example where it was drawn from European law or from an international treaty. ${ }^{11}$ In cases where the law in question is purely national, " $t$ ] he weight of foreign solutions is always limited. All reports agree that no court bases its decision solely on a foreign rule. The recourse to foreign law furnishes but a supplementary element for the court's reasoning.'

But, as Mak suggests, if we want to assess the extent of globalisation, we need to distinguish between a number of different issues. ${ }^{13}$ One question is whether judges are influenced in their approach to issues by the decisions of courts in other jurisdictions. Do these decisions help them to form a view about the right legal solution? A second question is whether, in the process of discovering the law, they make use of such decisions from other jurisdictions-are they raw material that they seek out within their searches? As I have noted elsewhere, ${ }^{14}$ foreign decisions offering different solutions to established domestic law may cause domestic judges to question whether the established solution is really required. The existence of alternative foreign solutions may trigger debate on the right domestic solution, even if the foreign law is not, in itself, a justification for any new solution reached in domestic law. A third question is whether foreign cases find their way into the justifications offered by judges as a result in the case.

The three questions require very different kinds of evidence and research methodology. In particular, there is a significant issue about the causative weight to be attributed to any particular factor. At best, researchers are looking to

\footnotetext{
${ }^{10}$ See e.g. Lawrence v Texas, 539 US 558, 598 (2002) and Roper v Simmons, 543 US 551, 622-28 (2005); Basil Markesinis with Jörg Fedtke, Engaging with Foreign Law (2nd edn, 2009) 195-203.

${ }^{11}$ U Drobnig, 'General Report', in U Drobnig \& S van Erp (eds), The Use of Comparative Law by Courts (1999) 3-21.

${ }^{12}$ Ibid, 18.

${ }^{13}$ Mak, above n 8, 215.

${ }^{14} \mathrm{~J}$ Bell, 'The Argumentative Status of Foreign Legal Arguments' (2012) 8 Utrecht LR 8, 17.
} 
identify contributing factors that, taken together, create a plausible account of how things work. In particular, it is wrong to think of there being single causes.

\subsection{Influences}

Bobek rightly notes that comparative law may be cited in novel or complex cases where national rules may be unclear, unsatisfactory or be lacking. ${ }^{15}$ Foreign law serves as inspiration in this context. But, if materials are merely inspiration, then they are not essential to be included as references. Reading such materials constitutes intellectual engagement, but citing them has another purpose-it serves to add authority to the decision reached or to the decision-maker. Bobek rightly points out that judges will not always cite everything they have read. For a start, as in France or the Netherlands, Sweden or Slovakia, the conventions of writing judgments may be such that only mandatory sources may be cited. A case can only be cited if it leads imperatively to the solution. Furthermore, even in other systems, inspiration as to principle or approach is less likely to be cited than solutions. ${ }^{16}$ If the function of the judgment is to convince the reader that the right decision has been reached according to law, then it is not always necessary to give evidence of all the steps in the reasoning. The legitimacy of a decision may rely essentially on an appeal to authority-the rule laid down by a particular organ of government (the legislature or the executive). Substantive legitimacy, where one persuades the reader of the correctness of that interpretation of the law is a different matter. So the classic authority on writing judgments of the French Cour de cassation argues that one should not provide the reasons behind a ruling:

We consider [...] that it is necessary to abstain from 'giving reasons for the reasons', in the sense that, in a judicial decision the inclusion of the essential reasons meets an absolute necessity, the explanation of those reasons departs from the field of law in bringing in considerations which are more or less subjective and contingent $[\ldots]^{17}$

Furthermore, a court may not have the time or the resources to conduct a proper presentation of foreign law. Transparency serves to encourage consensus

\footnotetext{
${ }^{15}$ M Bobek, Comparative Reasoning in European Supreme Courts (2013) 245.

16 Ibid, 229.

${ }^{17}$ A Perdriau, La pratique des arrêts civils de la Cour de cassation (1993) \$1299 (my translation).
} 
and cohesion, but there may be reasons of practicability which limit the full justification of decisions. Without research assistance, courts may have to focus on the essential elements in a judgment-getting the facts right and the essential rule of a decision. The Cour de cassation reaches over 28,000 decisions in a year, and maybe as many as 80 cases in a hearing. Even the Advocate General preparing the opinion for the decision will not have the time to examine the implications of all matters. If references to foreign law are auxiliary arguments, then they will suffer from the need for judges to be focused and concise in their decisions. As Bobek puts it, "[a] decision "saying too much" and presenting itself as an intricate web of references, cross-references, considerations, and debates may be as problematic as a decision saying too little. ${ }^{18}$ If the main audience for the decision (other than the parties) is the lower courts, then a ruling that is workmanlike and serviceable may be sufficient. Bobek argues that transparency may give way to pragmatism:

For [...] pragmatic reasons, comparative arguments may be in the end often left out of a judicial decision. Their main role is seen as one of finding a solution and/or for justifying it internally, providing the judges with merely mental comfort that the solution they opted for is not completely unheard of. However, as comparative arguments in instances of non-mandatory uses of foreign law will always be just additional or supporting, and judges may often be uncertain about their correctness as well as the universal appeal of the authority chosen for the inspiration drawn, then why make the decision more vulnerable to challenge by including it? ${ }^{19}$

So, he concludes that there may well be very good reasons why foreign materials that have been read by judges and which may have had an influence on the solution they reach will nevertheless not feature in the judgment.

The study of influence is consequently very diffuse. Influence involves the shaping of opinions and perceptions. That occurs in a variety of ways, not just by reading materials which are presented within the framework of a formal judicial decision. The research conducted on this area has used two different forms of analysis. One involves the study of networks. ${ }^{20}$ In this study, Claes and de

\footnotetext{
${ }^{18}$ Bobek, above n 15, 235.

${ }^{19}$ Ibid, 234.

${ }^{20}$ M Claes \& M de Visser, 'Are You Networked Yet? On Dialogues and European Judicial Networks' (2012) 8 Utrecht LR 100, 106-12.
} 
Visser explain how associations and internet connections provide the fora for the exchange of ideas amongst judges. Such networks facilitate face-to face meetings, periods of stay or observation in foreign courts. In terms of the use made of these interactions, they distinguish between 'practical' and 'authority' incentives.

'Practical' incentives are concerned with the pressures of globalisation for the actors involved in the judicial business. Participating in networks is not so much a matter of choice but of necessity to make sure that judges are still able to get the job done properly in a changing environment. The internationalised nature of litigation makes knowledge about other legal systems a prerequisite to being able to dispense justice in an individual case. These considerations take on an extra dimension within the European Union $(E U)$, with its quest to establish a truly internal market and the ever-expanding reach of EU rules. ${ }^{21}$

By contrast, “[a]uthority” incentives denote membership of judicial networks for the purposes of borrowing or enhancing the participating court's authority and legitimacy. ${ }^{22}$ Participation in a network may enhance the status of a court in the sight of judges from other countries or it may confer an additional aura of authority in its internal dealing within the legal system-being associated with others may enhance the authority of the domestic institution. ${ }^{23}$ Particularly in the European context, they see the network as working alongside more formal structures, such as the preliminary reference to enable national judges to gain a more European perspective on the interpretation of common norms. ${ }^{24}$ Supra-national courts such as the European Court of Justice and the European Court of Human Rights foster such informal networking events, at least with national opinion formers, in order to create a common ethos within which individual decisions will be decided. Data is often available on the associations and conferences of which judges are a part. That does permit network analysis of who is meeting with whom and how frequently. But then there is the need for interpretation. It is here that Alan Paterson ${ }^{25}$ and Elaine $\mathrm{Mak}^{26}$ have resorted to elite interviews in order to ascertain the perception of the participants about the significance of such networking and its influence on decision-making. ${ }^{27}$ They conclude that national judges seek to influence supranational judges and vice

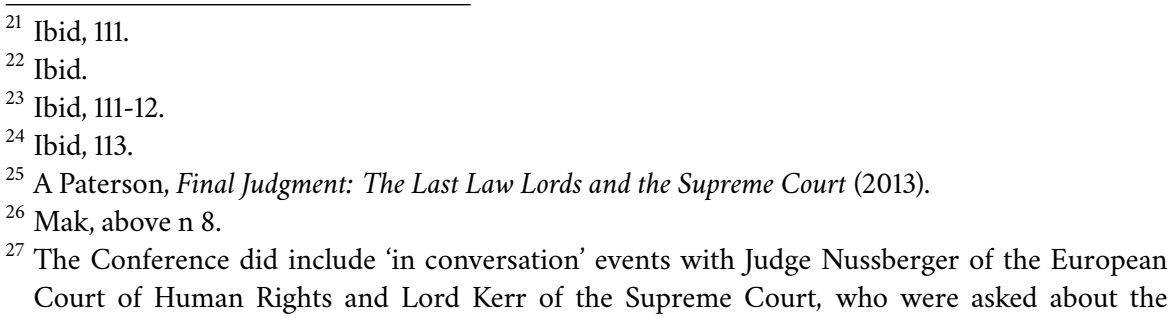


versa. There is not a one-way street. Supranational judges gain a sense of the importance of particular issues at a national level and national judges gain some sense of why supranational judges take a different view. For example, Mak notes that there were divergent views on the utility of international exchanges amongst the judges to whom she talked. Some thought them important and others did not see how they would change much of what judges ordinarily did. ${ }^{28}$ At best, it enabled judges to benchmark their approaches to other systems, especially those that were similar in terms of legal tradition or geography. ${ }^{29}$ Certain judges are more likely to take up these opportunities than others. But the conclusions both reach is that the number and variety of such exchanges has increased.

Rather like the meals in the Inns of Court, the effect of informal interaction is to socialise lawyers to be part of a collective effort. This is clearly an important feature of supranational courts such as the European Court of Justice, which organises regular visits from leading judges and others from its different legal systems, so they can understand the approach of the Court and that their concerns can be raised informally. Although this is important and care is put into the various forms of socialisation, it is difficult to demonstrate clearly any effect.

\subsection{Sources}

If 'inspiration' may appear more elusive to document, then the idea of sources might seem more specific. An account of sources tracks the logic of discovery. It explains how the decision was reached, in contrast to the logic of justification which presents why the wider public ought to treat the decision as rightly decided. Sources may be either 'material sources', what the lawyers present as evidence of the law, such as textbooks, case reports and the like, and 'normative sources' the rules which are found within those statements of the law. Rodolfo Sacco describes how the different formulations of the law, its 'formants', provide the raw material out of which a particular formulation of the law is drawn. ${ }^{30}$ On this conception, national law is never completely formulated. In many cases, the task of applying the law involves an element of completing its formulation. This section looks at the foreign materials as possibly containing such formulations of the law.

Drobnig noted the value of comparative material as a source of information, but argued that it was scholarly writing as an indirect source, rather than judicial

\footnotetext{
relationships, formal and informal, between the two courts.

${ }^{28} \mathrm{Mak}$, above $\mathrm{n} 8$, see especially $104-5,113$.

29 Ibid, 101.

${ }^{30}$ R Sacco, 'Legal Formants: A Dynamic Approach to Comparative Law' (1991) 39 AJCL 1, 22.
} 
decisions as a primary source which counted the most:

Comparative literature written in the court's language is another helpful source of information. The recourse to comparative literature has the additional advantage that one may expect, at least in general, a balanced account of the foreign law in question; that assists the courts to guard against prejudiced, one-sided information. ${ }^{31}$

Writing nearly twenty years later, Bobek comes to a similar conclusion:

The study of Continental jurisdictions revealed, certainly at least as far as the scholarly and judicial statements were concerned, a clear preference for scholarly comparisons. Foreign ideas are most welcome in courts. They should nonetheless first be filtered, discussed, and adapted by the legal scholarship. ${ }^{32}$

There is, no doubt, a difference in the approach of common law countries. They are more used to looking at judicial decisions and would tend to cite them directly, rather than being mediated by textbook writers. But then there will come the concern that the view presented by the parties or researched by the court's own assistants is incomplete and only partly understood. Or it may be argued that judges are choosing one jurisdiction and ignoring another-'cherry picking'. It is here that Markesinis suggests that foreign law needs to be 'packaged' not just with summaries of cases, but with practical information about how the law works in practice and how solutions are provided for individuals. ${ }^{33}$

Since foreign materials may not be in languages read by the individual judges, judges will often rely on translations by others or digests by either counsel or by judicial assistants (where these exist). It is the importance of judicial assistants in recent years that has transformed the capability of higher courts to engage in drawing on foreign materials. The availability of such assistance is variable. Whereas the Conseil d'Etat now has a group dedicated to the provision of comparative legal information, other courts have no such assistance. ${ }^{34}$ Mak too notes that research is undertaken in courts on foreign legal materials, but this is not systematic and depends especially on the availability of research

\footnotetext{
${ }^{31}$ Drobnig, above n 11, 19.

32 Bobek, above n 15, 193 (emphasis original).

${ }^{33}$ Markesinis, above n 10, 294-303.

${ }^{34}$ Bobek, above n 15, 46-7.
} 
assistance and the accessibility of the sources to be consulted (in terms of location and language). ${ }^{35}$ But, realistically, the complexity of mandatory foreign legal references (the need in Europe to ensure that there are no decisions of the European Court of Human Rights or the European Court of Justice that are overlooked and the need to examine rulings in relation to international treaties) leaves very limited space for engaging with non-mandatory materials. ${ }^{36}$

Availability, accessibility and reliability are all essential requirements before any material sources of law can be read with profit to discern potential normative principles and solutions against which the otherwise applicable national law can be measured. The studies undertaken do not suggest that the parties' lawyers are able or willing to provide presentations of foreign law which are sufficiently comprehensive and objective. Without the packaging that Markesinis talks about, judges have good reason to be sceptical about the quality of what they are being presented. Greater reliability can be found in the researches conducted in-house by the judge's own assistants or by the court's own documentation team or comparative research unit. Bobek is realistic in his conclusions. Cases in which a court would formulate a fully-fledged comparative argument, establish points of comparison, define the element with respect to which it compares, evaluate the findings, and then integrate its acquired comparative knowledge clearly into its reasoning, are very rare, or rather non-existent. ${ }^{37}$

Even in Germany, the use of comparative law in the courtroom has been described as 'disappointing. ${ }^{38}$ Bobek concludes that in qualitative terms, the process of reading foreign law sources is 'highly selective and non-representative. ${ }^{39}$ When judges refer to the materials for foreign jurisdictions, they are acknowledging where ideas came from, rather than any scientific objectivity in the analysis of the state of global laws (or even regional laws). If that can be provided by intermediaries, such as scholars or law reform commissions, all well and good, and that adds authority to the decision reached. But that is not an outcome for which the court itself has strived. Indeed, Bobek concludes, like Markesinis, that the responsibility for getting foreign law ideas into the minds of judges lies with the academics: ' $[\mathrm{t}$ ]his primary responsibility cannot be passed onto the judges by declaring that it is now the duty of courts to become places of comparative study. ${ }^{40}$

\footnotetext{
${ }^{35}$ Mak, above n 8, 119.

${ }^{36}$ Bobek, above n 15, 194-5.

${ }^{37}$ Bobek, above n 15, 234-6.

${ }^{38}$ Markesinis, above n 10, 182.

${ }^{39}$ Bobek, above n 15, 247 (emphasis original).

${ }^{40}$ Bobek, above n 15, 287; Markesinis, above n 10, 302-3.
} 


\subsection{Justifications}

The study of citations might seem more straightforward, but it is actually quite difficult. It is a commonplace that citation practices vary from one legal system to another (and even within legal systems). Some judgments are long and contain references in great detail, others are short and contain almost no references. There is a difference in national style that is well documented. In his recent research, Bobek refines the discussion of the citation of comparative arguments significantly. As he points out, when they cite foreign precedents, judges are seeking inspiration, not authoritative reasons, and so the category of his research focuses on 'non-mandatory' arguments, those where the judge is not obliged to discuss foreign precedents. But mere citation is not comparison. ${ }^{41}$ Citation can be a mere adornment to a judicial argument, or a polite acknowledgement of the work of counsel or judicial assistants in the case. Bobek rightly suggests that we need to focus on situations in which there is sufficient engagement with the arguments of a foreign legal system that it constitutes one of the reasons for the instant court's decision. Now this is quite difficult to research.

First, the articulation of reasons for decisions is more elaborate in some systems than in others. Bobek describes systems with justifications limited to mandatory sources as 'dogmatically closed' and others as 'dogmatically open ${ }^{\prime 42}$. If the comparative reasons are not essential, but supportive, then they might well be omitted in a system (like the French) whose judgments focus only on necessary reasons for decisions. This is true, even if one narrows the enquiry to justifications, as opposed to influences on decisions. The work of Mitchel Lasser reminds us that the explicit presentation of policy justifications is not common in the French system and is only present to a limited extent in the ECJ. ${ }^{43}$ The function of the judgment is to provide rulings on which parties and lower court judges can rely. The policy justifications may be debated within the court or in wider for a within the legal community, but they do not count as sufficiently essential points to be included in the formal justifications for a decision.

Secondly, practical considerations affect whether a court can really make effective use of these reasons. Do the deciding judges have time to look at the materials or to understand their legal context? Are not judges likely to be criticised for 'cherry picking' in their choice of material from another system? ${ }^{44}$

\footnotetext{
${ }^{41}$ Bobek, above $\mathrm{n} 15$, see especially ch 10 .

${ }^{42}$ Bobek, above n 15, 197.

${ }^{43}$ M Lasser, Judicial Deliberations (2004) 157-61.

${ }^{44}$ See Mak, above n 8, 205 for an articulation of this concern by judges themselves.
} 
Especially in supreme courts with a very large throughput of decisions, the discussion of ancillary reasons for decisions is a luxury. In such contexts, however influential such arguments might be, they may well not be turned into formal and explicit reasons for a decision.

Thirdly, evidence is only readily available about 'institutional' reasons, ones provided within judgments or formal preparatory materials. Mak, in her interviews, is able to show that a number of matters, including foreign law, are considered by judges in their deliberations, but do not appear in the judgment. ${ }^{45}$ She quotes a French judge who drew the analogy with scaffolding. Foreign law provides inspiration whose presence may be obvious during the construction work, but once the building is complete, the scaffolding is taken down and it leaves no trace of its presence in the structure of the completed building. ${ }^{46} \mathrm{Her}$ research and that of Alan Paterson was replicated at the Conference when Lord Kerr and Judge Angelika Nussberger explained about the importance of informal conversations between judges helping to shape the way formally decisions of the supreme courts are used. An important feature of this context is the extent to which the domestic judge considers himself as part of a team which extends to include the foreign courts.

Recent studies by Bobek, Groppi and Ponthoreau, and Gelter and Siems all have made use of statistical data on citations, but all are very cautious about the results. ${ }^{47}$ The first methodological problem is that explicit citations cannot simply be taken to be the evidence of formal influence within justifications. Bobek's careful study of the use of citations in a number of jurisdictions shows that formal citations are not a reliable guide to the influence of judicial decisions. Indeed Mak concludes 'the experiences of the Dutch and French judges [...] provide evidence that the highest national courts consult the case law of courts in other jurisdictions more frequently than might be expected on the basis of an analysis of their published judgments. ${ }^{48}$

Even with those reservations, there are still issues about what the statistical information reveals. In the Groppi and Ponthoreau collection, each of the authors studying a particular country was asked to generate statistical data on citation

\footnotetext{
${ }^{45}$ Ibid, ch 5.

${ }^{46}$ Ibid, 159.

${ }^{47}$ These studies have attempted to be more 'scientific' in their approach compared with earlier studies that have mainly involved essays written on particular countries that draw on reflections (often of judges) in relation to particular prominent cases in their jurisdiction: see e.g. Drobnig and van Erp, above $\mathrm{n} 11$; Andenas \& Fairgrieve, above $\mathrm{n} 9$.

${ }^{48}$ Mak, above n 8, 198.
} 
in constitutional supreme courts. This produced some wide divergences on the frequency of citation of foreign courts and when this was undertaken. Namibia, South Africa, Canada, India and Ireland were much more frequent in their citation than many other countries. Bobek also notes that certain countries were looking outside for ideas at particular formative points in their constitutional development. ${ }^{49}$ The dynamics on which both Groppi and Ponthoreau and Bobek seize are the internal dynamics of a country-where it is in its constitutional development, how many national cases it has on which to draw, and thus where the value-added of citation lies. Whereas there are specific reasons offered why judges in particular countries are 'open' to the use of foreign judicial decisions as justifications, it is far more difficult to generalise.

For the most part, citation data serve to reveal patterns in citation which can then trigger questions about how particular systems operate. The data that Gelter and Siems have developed is more sophisticated than that of Groppi and Pontoreau, but points in similar directions. ${ }^{50}$ They looked at all the decisions of ten Supreme Courts in Europe over eight years. They also corrected for the absence of formal citation in French and similar judgments, by looking at opinions of the reporter judge, where available. They also filtered out situations where European law was involved and so citation of other courts was required. But even just looking at areas of law that were common to the courts studied, the pattern of citation was very diverse. ${ }^{51}$

Mak has conducted interviews with judges from a number of supreme courts and concludes that they worry more about finding arguments that they find compelling, rather than about their precise status as authority reasons for a decision. $^{52}$ All the same, it does matter whether foreign decisions are used as justifications, because that demonstrates not merely the interconnectedness of legal systems, but also a different attitude to the sources of law. I have suggested that it is best not to seek uses of foreign law as independently weighty justifications for a judicial decision. In most legal systems, single previous decisions do not provide adequately weighty justifications. ${ }^{53}$ But consistent lines of case law may well do so. The accumulation of reasons may provide a reinforcement of a particular result. The priority of the national law justifications

\footnotetext{
${ }^{49}$ Bobek, above n 15, 207-10.

${ }^{50}$ M Gelter \& M Siems, 'Citations to Foreign Courts - Illegitimate and Superfluous, or Unavoidable? Evidence from Europe' (2014) 62 AJCL 35.

${ }^{51}$ Ibid, Table 4, 48.

${ }^{52}$ Ibid, 48 (fn 2).

${ }^{53}$ Bell, above n 14, 10 .
} 
is not lost, but those justifications are given added lustre if they are embellished by justifications from decisions in other jurisdictions. But the ability of the foreign law to add weight or lustre to available domestic legal arguments will depend on the reputation of the foreign court or legislature as well as the attractiveness of the solution. So it is not so much that a foreign judgment supplants a domestic judgment, but that it enhances the standing of existing domestic options. Mak's analysis based on interviews confirms this picture. She suggests that, on the one hand:

Judges with an interest to learn about non-binding foreign legal sources can be found in all of the examined highest courts. However, the judges generally consider the usefulness of comparative law for judicial decision-making should not be over-rated. ${ }^{54}$

On the other hand, she does consider that they have some significant influence:

Although the use of such foreign legal materials is not always easily apparent in the published judgments, the interviews clarify that foreign law is studied and discussed and if not persuasive at least has a guiding role in the deciding of some domestic cases. ${ }^{55}$

So these contextual features serve to determine the use that might be made of foreign law in particular legal systems.

The analysis of citations does, however, reveal some features that are of particular importance to the study of globalisation. The pattern of citation is predominantly to another legal system in the same legal family or that has influenced legal development-so the Austrians cite overwhelmingly Germany and occasionally Switzerland, the Irish overwhelmingly the English, Spain cites Germany. There is a clear clustering of citations. ${ }^{56}$ Much of the clustering makes sense in terms of legal families, geographical proximity and language. Not surprisingly, England and Ireland stand apart from some of the other European countries. Legal tradition is a significant feature. Indeed the three major factors in cross-citation are accessibility, the authoritativeness of a court and the similarity of the jurisdiction. ${ }^{57}$

\footnotetext{
${ }^{54}$ Mak, above n 8, 162.

55 Ibid, 198.

${ }^{56}$ Gelter \& Siems, above n 50, 51.

${ }^{57}$ Ibid, 58-9.
} 
Groppi and Ponthoreau also identify legal tradition and language as having the greatest correlation in determining the foreign countries whose court decisions are cited. ${ }^{58}$ Their study includes jurisdictions in Africa, Asia and North America. For them, 'the research shows the absence of explicit transjudicial communication. Not only are there few countries where explicit citations are used, but the number of countries quoted is limited as well. ${ }^{59}$ Courts are seen as good, according to this research, in contextualising their foreign precedents according to their relevance to the constitutional and legal system from which they come. These two analyses suggest that the citation of foreign precedents is not an example of globalisation at work. It is not an example of worldwide problems being tackled by the development of worldwide solutions. Instead, we see courts starting with their own specific legal problems and then looking for accessible decisions from countries with constitutional and legal systems like theirs. The other feature is that comparison is limited to certain fields of law. Groppi and Ponthoreau looked at constitutional courts and, inevitably, human rights was the most prominent for foreign citations, but also novel social problems that were facing a lot of countries. ${ }^{60}$ They cite the Austrian courts as having a low rate of citing explicitly foreign judgments. But Gelter and Siems look at private law cases and find that Austrian supreme courts have a very high rate of citation of foreign cases (mainly from Germany). ${ }^{61}$ This is particularly common in fields of insurance law and unfair competition, where there are similar legal provisions between Austria and Germany. The clash of conclusions suggests that the interpretation of the data can be quite difficult.

Analysed in terms of clusters and, in the case of Gelter and Siems, by regression analysis to identify correlates, the quantitative research reveals patterns that would not be obvious from the approach of the earlier collections of Drobnig and van Erp or Canivet, Andenas and Fairgrieve. Their more anecdotal approach is more encouraging about the idea of cross-citation as an emerging and significant phenomenon. While the quantitative data is not able to measure the scale of the phenomenon, it is able to reveal patterns and inherent logic in what is occurring. The particular constitutional context and provisions of Namibia and South Africa give a particular impetus to cross-citation in constitutional cases, but this is not a universal phenomenon. The analysis of Europe has to exclude consideration of situations where national courts are simply applying regional norms as

\footnotetext{
${ }^{58}$ Groppi \& Ponthoreau, above n 7, 412-13, 419.

${ }^{59}$ Ibid, 420-1.

${ }^{60}$ Groppi \& Ponthoreau, above n 7, 416-17.

${ }^{61}$ Gelter \& Siems, above n 50, 60.
} 
determined by courts in Strasbourg or Luxembourg. Most of the data just reveals the importance of legal traditions and the similarities to which they have given rise. They also reveal the importance of cross-citations in smaller jurisdictions like Namibia, Ireland and Austria which do not necessarily have a large pool of domestic cases on which to draw.

Quantitative analysis focuses on the fact that foreign jurisdictions are cited. It does not say much about the significance of their citation. That requires qualitative research. Whilst Bobek and Mak show that there is value in reading individual judicial decisions contextually and interpreting them, greater value seems to be gained by Mak through conducting elite interviews with a few judges and using this as an interpretative device. Her interviewed judges identified several reasons for consulting foreign legal sources:

The use of non-binding foreign legal sources is considered useful, first, when the case to be decided holds particular public importance. Secondly, comparative legal materials are considered helpful when judges want to obtain better knowledge or a yardstick for the judgment of the case at hand. Thirdly, judges measure themselves with other courts and want to meet the same quality standards as their 'peers' in other jurisdictions. Finally, the research of non-binding foreign legal materials allows judges to spot trends regarding the evolution of the law in other legal systems and to determine their own position regarding these trends. ${ }^{62}$

This suggests that there is evidence of a greater global perspective within which some important judicial decisions are taken by the higher courts. But we need to be cautious about making claims that this demonstrates a major trend towards a system of global justice.

\section{Conclusions for globalisation}

If we go back to the Conference theme, the evidence from recent research is unanimously more cautious in claiming that there is a trend towards a global justice. Everyone agrees that there are increasing instances of legal rules adopted at international or regional level that require national legal orders to converge on solutions and to be in line with each other. Either through formal institutions

${ }^{62}$ Mak, above n 8, 201. 
that have the mission of ensuring uniform application of these common rules, or through informal cooperation, significant areas of social life are subject to global or regional common rules and principles, rather than being governed in many varied ways by national legal systems. This is the area that all the research identifies as the 'mandatory' area of citing external legal materials. But the claim of the conference theme and the suggestions of some comparative lawyers is that there is also a trend to viewing the law, even in non-mandatory areas, as part of a global enterprise of achieving justice. The evidence for this is much less strong. National judges are sometimes looking beyond their own system, but tend predominantly to pay attention to systems that are similar because of legal tradition and language. These are the ones where they are surer of being able to access the materials and to assess the results.

Bobek comments that " $t$ the often voiced claims concerning "global" judicial communities and "global" judicial mindset or outlook are therefore not empirically warranted, certainly not in today's Europe. ${ }^{63}$ Mak is more optimistic, ${ }^{64}$ but she recognises that comparing foreign legal solutions is less used in nonmandatory cases and is likely to be the subject of more criticism. Both agree that, in areas, such as human rights, where there are either mandatory common legal provisions or there are similar problems not clearly resolved by national law, then foreign law serves as a benchmark and encourages judges to examine best practice in other countries to see if useful lessons can be learnt. All the same, there are numerous limitations to this process. What do we conclude? First, perhaps to be less ambitious in the search for globalisation. Judges remain national actors and apply national provisions that are relatively clear most of the time. Supranational norms are an increasing part of the role, especially in the highest courts, but effort will inevitably concentrate on the essential areas in which foreign law needs to be consulted. But the 'spillover' effect is important. If networks of judges need to exist for essential work on mandatory norms, then conversation will move to other matters as well. The world has not become one single global judicial order, but there are incremental steps. The steps are through adding regional norms to the traditional focus on countries linked by language and a common legal tradition. But it remains true that the use of foreign legal materials is common mainly in some branches of law more than others, in relation to some countries more than others, and by some judges more than others.

\footnotetext{
${ }^{63}$ Bobek, above n 15, 197.

${ }^{64}$ Mak, above n 8, 230-1, 236.
} 


\section{Conclusions for research}

What implications for research teams? The problem of globalisation in law is complex because we are not dealing with the search for a universal solution to common problems. National judges are benchmarking national solutions against other national solutions and also against the standards adopted by some regional courts, such as the European Court of Human Rights. Such a situation makes the work of the individual scholar problematic. A lone scholar can tackle a universal problem in broad terms without worrying about the specific circumstances in which it is instantiated. But if the problem involves the interaction of a multiplicity of levels of legal regulation and those multiple levels may have differential results between countries, then it becomes difficult for a single scholar to undertake the necessary research. To go back to our issue of the asylum seeker, even if we confine our attention to Western Europe, then it becomes necessary to examine several jurisdictions. The results of research on England or the Netherlands, may not be replicated in Germany or Spain. The problem of managing asylum claims within the same regional legal framework may yet yield significantly different results between legal systems.

To examine whether this is the case, a number of specific problems have to be studied within a number of legal systems. In my example, someone has to be able not just to read English, Spanish, German and Dutch, but also to be sufficiently familiar with the way problems are resolved in practice to know whether it is sufficient to focus on national rules, or whether it is necessary to examine regional or local rules, or even the place of private sector bodies in providing assistance to asylum seekers. For such a study to be manageable, it is necessary to bring together a team and draw on its expertise. So the universalising or globalising tendency of the conference's theme may actually require a more complex set of research questions that cannot be managed easily by a single person. A personal illustration may make the point. My Judiciaries in Europe ${ }^{65}$ was the product of seven years of research on one problem (judicial careers) covering five countries. My more recent book with David Ibbetson on the history of tort law, 1850-2000, was the culmination of seven years of research on a range of problems within the broad theme of tort liability covering seven countries and involving 70 researchers and leading to nine books. ${ }^{66}$ There are limits to the achievement of the lone scholar. In the recent book, David Ibbetson and I

\footnotetext{
${ }^{65}$ Bell, above $\mathrm{n} 5$.

${ }^{66}$ J Bell \& D Ibbetson, European Legal Development: The Case of Tort (2012).
} 
were able to draw on the original research on very specific points undertaken by a wide range of experts reading their own language. In dialogue with each other, they were able to develop an understanding of the broader themes and we could use those materials as the basis for our own thinking. If the theme of the Conference is to be taken seriously, then it requires serious thought about the kinds of research project that can be undertaken and how the relationship between sole and collective research is best structured.

This article has drawn on the work of a number of lone scholars, especially Bobek and Mak. ${ }^{67}$ They looked at a few countries and a significant number of languages. They were able to use those particular skills to advance the subject. But they needed to build on the analysis of earlier collections of fairly unsystematic reflections, such of Drobnig and van $\operatorname{Erp}^{68}$ and Canivet, Andenas and Fairgrieve, ${ }^{69}$ which provided thoughtful insights and illustrations of a process. Importantly, the more systematic collective study by Groppi and Ponthoreau ${ }^{70}$ and the later work of Gelter and Siems ${ }^{71}$ have provided quantitative analysis, but again over a small but significant number of countries. A fuller picture of globalisation requires both coverage of a wide variety of countries and a variety of analyses, statistical, interview-based, and the reading of texts, and an understanding of the contexts out of which these materials are all arising. The different studies each contribute part of the picture. But it is clear that the initial insights in works such as Drobnig and van Erp needed to be subjected to much more rigorous analysis by subsequent scholarship. It is not sufficient to rely on the impressionistic analysis of academics or judges. More recent work shows different ways in which such rigorous analysis can be provided that is 'scientific' in the continental European use of that term. The challenge of the research question set out by the Conference organisers is how to build a multi-linguistic and multi-skilled team drawn from different legal traditions that is capable of delivering a more comprehensive body of evidence to provide a comprehensive answer.

\footnotetext{
${ }^{67}$ Bobek, above n 15 ; Mak, above n 8 , respectively.

${ }^{68}$ Drobnig, above $\mathrm{n} 11$.

${ }^{69}$ Andenas \& Fairgrieve, above $\mathrm{n} 9$.

${ }^{70}$ Groppi \& Ponthoreau, above $\mathrm{n} 7$.

${ }^{71}$ Gelter \& Siems, above n 50.
} 